\title{
Research on Levels of Knowledge of Youth in Field of Energy Efficiency and Renewable Energy Sources ${ }^{1}$
}

\author{
Dr. Amra Nuhanović \\ Associate Professor \\ Faculty of Economics and Business \\ University of Tuzla \\ Dr. Amra Babajić \\ Assistant Professor \\ Faculty of Economics and Business \\ University of Tuzla \\ Mr. Erna Herić \\ Senior assistant \\ Faculty of Economics and Business \\ University of Tuzla
}

\begin{abstract}
As youth find it easier to embrace new ways of thinking, this research sought to send important lessons/messages and develop awareness of the importance of energy efficiency and the use of renewable energy. Therefore, by continuing to educate and inform youth about these issues, they would directly influence both their own and the awareness of their parents or households in which they reside, with the aim of encouraging proper energy management, so that at the end, each family, through proper behavior and implementation of appropriate measures, with little additional cost, could save on energy costs. According to the foregoing, the main objective of the research is, in fact, to investigate knowledge levels of students in the $1^{\text {st }}$ cycle of studies at the Faculty of Economics and Business of University of Tuzla, in the field of energy efficiency and renewable sources. The methodology used in the paper is based on the use of primary (survey questionnaire) and secondary (desk research) data sources. The research results have shown a very low levels of knowledge and awareness of youth about the importance of energy efficiency and using renewable sources of energy, about the lack of informative and promotional activities in this field, as well as about the interest in environmental protection and energy consumption. Finally, insufficient involvement of youth in the decision-making process regarding energy efficiency and renewable energy was detected.
\end{abstract}

Keywords: youth, education, awareness, energy efficiency, renewable energy sources.

\section{Introduction}

Today, increasing energy deficits and increased energy consumption require creation of national and local programs designed solely to raise awareness of the population, in order to trigger action at the individual level. This actually means that the goal of any strategic activity is to reach out to a youth, who will indirectly stimulate thinking about energy efficiency and his/her household to which he or she belongs. Of course, it should be emphasized that there is a need at the level of every citizen, regardless of age, to reduce energy consumption and use energy in a sustainable way. In this regard, it is very important that municipalities and cities encourage and involve their citizens in frugal measures, contributing to the reduction of energy consumption and the impact on climate disasters.

Considering that youth accept new ways of thinking much easier, this research attempted to send important lessons/messages and to raise awareness about energy efficiency and consumption of renewable energy sources. In this way, youth will be continually informed and persist in changing for a better and more secure future, starting with themselves, their family or their household. Therefore, the specificity of the research problem relates to informing youth about these issues, both directly affecting the rise of their own level of consciousness and indirectly, the awareness of their parents or households in which they reside, with the aim of encouraging proper energy management,

${ }^{1}$ This paper has been created as a result of the project named „Education of Students from the Field of Energy Efficiency and Renewable Energy Sources“, supported by the Ministry of Science and Education for 2019. 
where in the end, each family, through proper behavior and the implementation of appropriate measures, without additional costs, could save on energy costs.

It is a well-known fact that increased energy efficiency results in lower environmental pollution costs and better protection of public health. Therefore, this research attempted to show youth first, that more efficient use of energy is the cheapest way to reduce energy consumption, that is, to save money that we spend on energy and reduce pollution. Energy efficiency involves improving the quality of life, and this research could make very important recommendations for youth to reduce their energy consumption in their home and daily life, and become energy efficient. Therefore, it is necessary to change the habits and awareness of youth about these issues through continuous education.

\section{Theoretical background}

Based on the presented findings, relatively few scientific papers have been published so far, addressing the level of knowledge and awareness among youth about the importance of extending energy efficiency and using renewable energy sources. The study aims to determine whether and to what extent youth (and through them, their households) pay attention to energy consumption, whether and to what extent they are aware of how they may reduce energy consumption, and what may be achieved by such action. Accordingly, the main objective of the research is to establish and analyze students' level of knowledge in the field of energy efficiency and renewable energy sources.

The following specific (or operational) objectives emerge from the main objective:

1. Contribute to increased education of students in the field of energy efficiency and renewable energy;

2. Raising students' awareness on the importance, that is, the benefits of energy efficiency and renewable energy sources.

Consideringtheexistingscientific knowledge about the importance of energy efficiency and renewable energy sources, explained in the second part of the paper, the theoretical concept of this research is presented in the following Image:

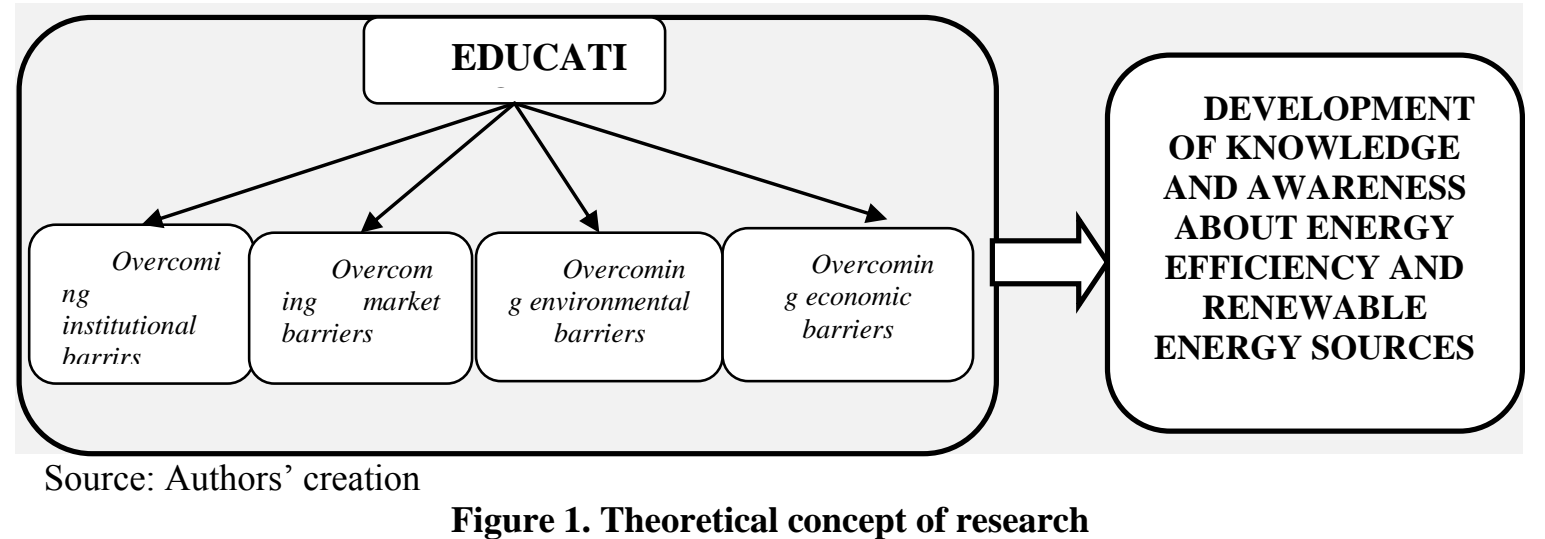

In accordance with the predefined subject and purpose of the research and the theoretical concept presented, the central research hypothesis is: Through education of youth about the institutional, market, environmental and economic aspects of energy economics, the level of knowledge and awareness of the importance of energy efficiency and the use of renewable energy may be raised.

The paper is organized as follows: Following the theoretical concept of the research, which is the first chapter of the paper, the second part gives a brief overview of the significant research results which addresses issues of energy efficiency and renewable energy sources, in general. The third part relates to the methodology of the conducted research, while the fourth part relates to research results and discussion. The concluding considerations summarize the main findings of the study.

\section{Previous research}

\subsection{Researches and empirical studies conducted in European countries in transition}

Studies to date have shown that educating and informing the public, especially youth, about energy efficiency is one of the key prerequisites for the wider use of renewable energy sources. Thus, the very idea of the importance of raising the level of knowledge and awareness of renewable energy sources is based on the assumption about the responsibility of an individual - a young man or woman - and developing his or her tendency towards being able to participate and make decisions in all environmental segments. Kavedzhi (2009) drew special attention to this, believing that effective education should not be one-sided, and apart from informing, it should aim to change the general attitude and approach to this issue. One of the foundational objectives in his research is directed towards the change of individuals themselves 
(for example, regarding the rationalization of their own energy consumption in daily life) and attitudes towards renewable energy sources. This objective is linked to the idea of accountability, especially citizens' own responsibility.

In accordance with the afore mentioned, the following will outline some examples of good practice in individual European countries, where in the last 10 years, intensive efforts have been made to raise awareness about energy efficiency in local households. For example, in Germany, as one of Europe's largest light source markets, a whole series of low-energy activities was carried out to popularize the use of energy-saving light bulbs in households and the public sector. Furthermore, in the Netherlands, the electricity distribution company sent a brochure to households informing them about benefits of using energy-saving bulbs. In addition to the brochure, they also received a coupon for a more affordable purchase. The same was done in Norway, through a strong media campaign and promotion. In order to popularize energy savings, Hungary purchased 125,000 energy-saving bulbs and installed them in as many as 267 government buildings (offices, hospitals and schools).

Citizen Participation Energy Efficiency Action Planning (2016) was the first major study in Croatia regarding information and education campaigns aimed at youth, and also at the general public regarding systematic energy management. The aim was to establish a so-called network of energy efficiency info points (or EE info points) where youth, as well as all interested citizens, may be informed about the possibilities of improving energy efficiency. Today, there are 107 such info points in Croatia. The great achievement of these activities was to raise the level of awareness of all citizens in Croatia about energy efficiency. Thus, public opinion polls reveal that the number of citizens who believe they can reduce energy consumption has increased from $27.9 \%$ to $47.7 \%$, and that the number of citizens familiar with energy efficient products on the market has increased from $33.4 \%$ to $43.9 \%$.

Interesting research findings can also be found in the work of Topićet al. (2018), based on the cross-border cooperation of the rural regions of Hungary and Croatia, in which the mentioned authors elaborated the level of development of awareness and knowledge about renewable energy sources among both youth and elderly. The results showed that the general knowledge amongst rural regions of Hungary-Croatia was at the "moderate" level. Therefore, about $50 \%$ of respondents had some prior knowledge of renewable energy sources, and as many respondents were willing to embrace solar energy based energy efficiency technologies in their local community.

In the Energy Efficiency Action Plan of Montenegro for the period 2019-2021, programs for information and education of youth take a special place. In that sense, several public and expert events were held and a different set of promotional material was prepared, intended primarily for particular target groups - youth and educational institutions (schools, faculties, etc.) to include the topic of energy efficiency in curricula at all levels, as well as carrying out certain promotional activities (seminars, round tables, knowledge quizzes, and such).

Also, according to Kolega\&Bošnjak (2015), continuous education and information campaigns for raising youth awareness, along with gender equality, is one of the steps for adequate implementation of energy efficiency and renewable energy measures. The special contribution of these authors was reflected in the fact that they covered the entire geospatial area of Southeastern Europe.

\subsection{Overview of studies to date in Bosnia and Herzegovina}

All findings presented and all the scientific papers published thus far in the area of Bosnia and Herzegovina (B\&H) state that the importance of energy efficiency and the use of renewable energy sources in B\&H is generally poorly promoted. Studies have shown that greater involvement of the government and non-government sectors is necessary in raising awareness and knowledge in the field of energy efficiency, especially towards youth. Unfortunately, institutional barriers to the development and support of energy efficiency are a particular problem, since there is no single state law on energy efficiency, which offers the same methodology for the Federation of B\&H and the Republic of Srpska.

Deutsche Gesellschaft'sfürnternationaleZusammenarbeit (GIZ) studies since 2016, primarily in the Republic of Srpska, are based solely on methodological explanations of legal obligations in the fields of energy management, energy efficiency, renewable energy sources, and $\mathrm{CO} 2$ emissions. The education of youth, as well as of the whole population, has been put aside.

Attempts to develop awareness and knowledge of youth in the field of energy efficiency are evident in the Federation of B\&H during 2016, with the help of Energis (Center for Education and Awareness Raising on the Need for Increasing Energy Efficiency), which continuously publishes studies on the topic. One of them is the "W\&E School" Waste \&Energy School (2016). Specifically, the survey included students from lower grades of primary schools in Sarajevo Canton, since young children have the greatest capacity to absorb new information and knowledge and the real fact that the education system in B\&H is often not, either adequately or sufficiently, focused on knowledge from areas of energy efficiency and the need to conserve the environment. 
Furthermore, the Federation of B\&H's Energy Strategy Framework until 2035 (2017) presents insufficient progress in developing programs and strategies to encourage the use of renewable energy sources, then educates youth and the public, and enables citizens to participate in energy management projects. In this regard, guidelines for improving education were given, in terms of: introducing public informative campaigns on energy efficiency to raise citizens' awareness, providing basic information on the importance of energy efficiency, raising motivation to carry out activities and achieve savings, and conducting activities aimed at informing the public, raising awareness of the need for energy savings, educating and training (energy) professionals.

Also, a study Civil Society Recommendation on a Faster Road to the European Union - in the Energy and Environment Sector, conducted under the "Citizens for Europe" Initiative, indicates that there is insufficient political interest in environmental issues and a low level of awareness among youth and the general public, as well as lack of public involvement in the decision-making process regarding energy efficiency and the use of renewable energy sources.

\section{Research Methodology}

Within the secondary research (desk research), available secondary sources of data and information were processed, for example, books, articles, publications and websites covering the field of energy efficiency and renewable energy sources, all with respect to the principles of reference and current literature used.

The primary data sources are collected to investigate youth's awareness and knowledge of the importance of energy efficiency and renewable energy, based on a survey questionnaire. The research involves students of the 1st cycle of studies at the Faculty of Economics, University of Tuzla. The test was conducted on a sample of 70 students going through a four year study. This part of the population has a high capacity to absorb new information and knowledge. However, it is noted that the existing formal education channels do not offer sufficient theoretical and practical knowledge in the field of energy efficiency and the use of renewable energy sources. Therefore, the targeted group for education are students aging from 20 to 24 years of ages, where both genders are equally represented (1:1). The collected data have been analyzed through a descriptive statistical method.

The research has lasted for three months, within which the following was realized: education, surveying, evaluation, that is, assessment of gained knowledge upon completion of the education. It is important to emphasize that each student has filled a questionnaire before and after the completion of the education.

\section{Analysis and Discussion}

Most of the surveyed students have finished a general secondary school - gymnasium or one of the secondary technical schools (economics school, electro-technic school, trade school). From those 70, 50 students $(71.5 \%)$ comes from the "urban" area, while $28.5 \%$ (20) students comes from the "rural" area. Considering that, Table 1 presents some of the basic characteristics of the sample.

Table 1. Basic characteristics of the sample

\begin{tabular}{|c|c|c|c|c|c|}
\hline \multicolumn{5}{|c|}{ Basic characteristics } & \multirow{2}{*}{ Total } \\
\hline \multirow{3}{*}{$\begin{array}{l}\text { Completed } \\
\text { secondary } \\
\text { school }\end{array}$} & $\begin{array}{r}\text { General } \\
\text { gymnasium }\end{array}$ & $\begin{array}{c}\text { Electro- } \\
\text { technic school }\end{array}$ & $\begin{array}{l}\text { Economics } \\
\text { school }\end{array}$ & $\begin{array}{c}\text { Trade and } \\
\text { catering school }\end{array}$ & \\
\hline & 15 & 3 & 35 & 17 & $70(\mathrm{n})$ \\
\hline & 21.43 & 4.29 & 50 & 24.29 & $100(\%)$ \\
\hline \multicolumn{6}{|l|}{$\operatorname{Sex}$} \\
\hline \multirow[t]{2}{*}{ Male } & 5 & 3 & 15 & 10 & $33(\mathrm{n})$ \\
\hline & 15.15 & 9.09 & 45.45 & 30.30 & $100(\%)$ \\
\hline \multirow[t]{2}{*}{ Female } & 10 & - & 20 & 7 & $37(n)$ \\
\hline & 27.02 & 0 & 54.05 & 18.92 & $100(\%)$ \\
\hline \multicolumn{6}{|c|}{ Area of residence } \\
\hline \multirow[t]{2}{*}{ Urban } & 5 & 3 & 25 & 17 & $50(n)$ \\
\hline & 10 & 6 & 50 & 34 & $100(\%)$ \\
\hline \multirow[t]{2}{*}{ Rural } & 10 & - & 10 & - & $20(n)$ \\
\hline & 50 & 0 & 50 & 0 & $100(\%)$ \\
\hline
\end{tabular}

Source: Authors' creation

When talking about foundational knowledge of the basics of energy efficiency and renewable energy sources, the results prior to education of students were very devastating. Table 2 presents the best illustration of this finding. 
Table 2. Knowledge of students a propos basics of energy efficiency and renewable energy sources

\begin{tabular}{|c|c|c|c|c|c|c|c|c|}
\hline \multirow{3}{*}{ Questions } & \multicolumn{4}{|c|}{ Pre education } & \multicolumn{4}{|c|}{ Post education } \\
\hline & \multicolumn{2}{|c|}{$\begin{array}{l}\text { Freque } \\
n c y\end{array}$} & \multicolumn{2}{|c|}{$\begin{array}{l}\text { Percentage } \\
(\%)\end{array}$} & \multicolumn{2}{|c|}{$\begin{array}{l}\quad \text { Freque } \\
\text { ncy }\end{array}$} & \multicolumn{2}{|c|}{$\begin{array}{l}\text { Percentag } \\
e(\%)\end{array}$} \\
\hline & $e^{2} Y$ & $o^{N}$ & Yes & No & $e^{Y} Y$ & $o^{N}$ & Yes & $\mathrm{o}^{\mathrm{N}}$ \\
\hline $\begin{array}{l}\text { Have you ever heard terms energy } \\
\text { efficiency, renewable and non- } \\
\text { renewable energy sources? }\end{array}$ & $0^{5}$ & $0^{2}$ & $\begin{array}{l}71 . \\
43\end{array}$ & $\begin{array}{l}28.5 \\
7\end{array}$ & $0^{7}$ & 0 & $\begin{array}{l}100 \\
.00\end{array}$ & $\begin{array}{c}0 \\
, 00\end{array}$ \\
\hline $\begin{array}{l}\text { Do you know that non-renewable } \\
\text { energy sources include (amongst } \\
\text { others) fossil fuels (coal, oil, natural } \\
\text { gas)? }\end{array}$ & $0^{2}$ & $0^{5}$ & $\begin{array}{l}28 . \\
57\end{array}$ & $\begin{array}{l}71.4 \\
3\end{array}$ & $0^{7}$ & 0 & $\begin{array}{l}100 \\
.00\end{array}$ & $\begin{array}{c}0 \\
, 00\end{array}$ \\
\hline $\begin{array}{l}\text { Do you know that renewable energy } \\
\text { sources include energy from wind, sun, } \\
\text { water? }\end{array}$ & $7^{1}$ & $3^{5}$ & $\begin{array}{l}24 . \\
29\end{array}$ & $\begin{array}{l}75.7 \\
1\end{array}$ & $0^{7}$ & 0 & $\begin{array}{l}100 \\
.00\end{array}$ & $\begin{array}{c}0 \\
, 00\end{array}$ \\
\hline
\end{tabular}

Source: Authors' creation

Further, as support to the above, it is a fact that from those 70 surveyed, $50(71.43 \%)$ did not know the classification of non-renewable energy sources (fossil fuels, oil, coal, natural gas). It is a similar situation with the basic classification of renewable energy sources (energy from wind, sun and water), where approximately 53 students, or $75.71 \%$ of them was not familiar with it (Graph 1).

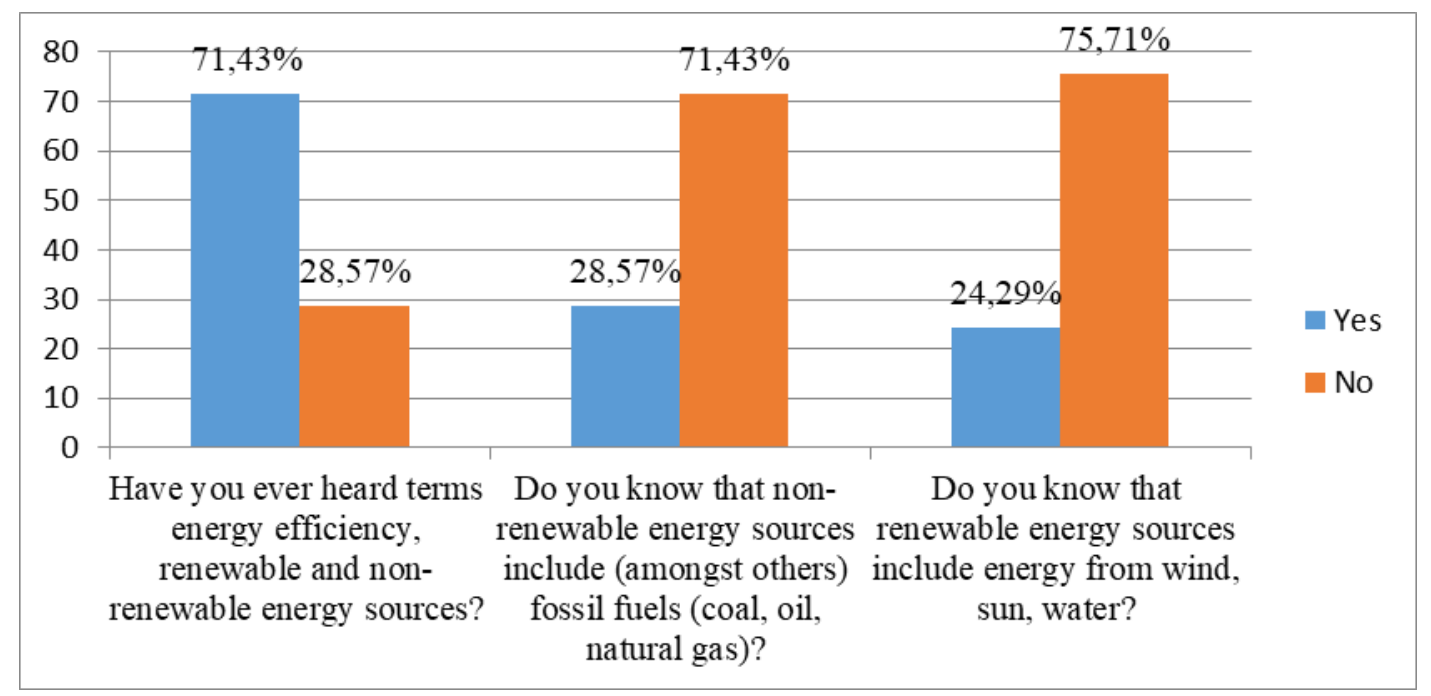

Source: Author's creation

\section{Graph 1.Researching students' level of knowledge regarding basics of energy efficiency and renewable energy sources}

After education of students about the basics of renewable and non-renewable energy sources, all 70 students (100\%) was completely familiar with named terms, and they know how to correctly answer and classify their definition.

Further, it is interesting to note that only $7.14 \%$ students use LED lights in their household. This is best illustrated in Graph 2. When asked to name reasons for using LED lights in their households, 100\% of students stated that the reason is the lack of knowledge.

Therefore, reasons were not lack of monetary funds or that members of their households do not support such type of lighting (which was perhaps expected prior to during data processing!) 


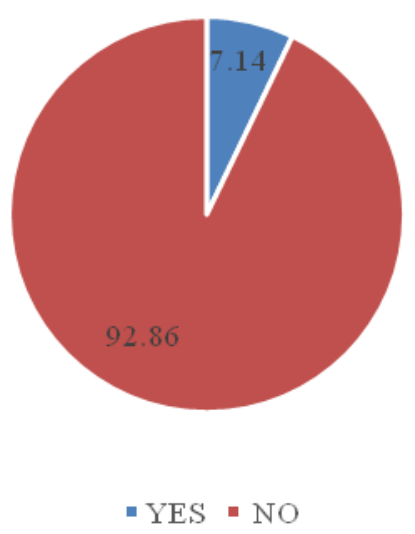

Graph 2.Do you use LED bulbs in your own household?

Source: Author's creation

The assumption that youth do not have adequately high awareness about energy is supported by data that only $14.29 \%$ of them use pellet as a main source of heat in their households. The following Graph 3, it is presented that central heating is used by $45.71 \%$ of their households, and approximately $40 \%$ use solid fuels (wood, coal, and such).

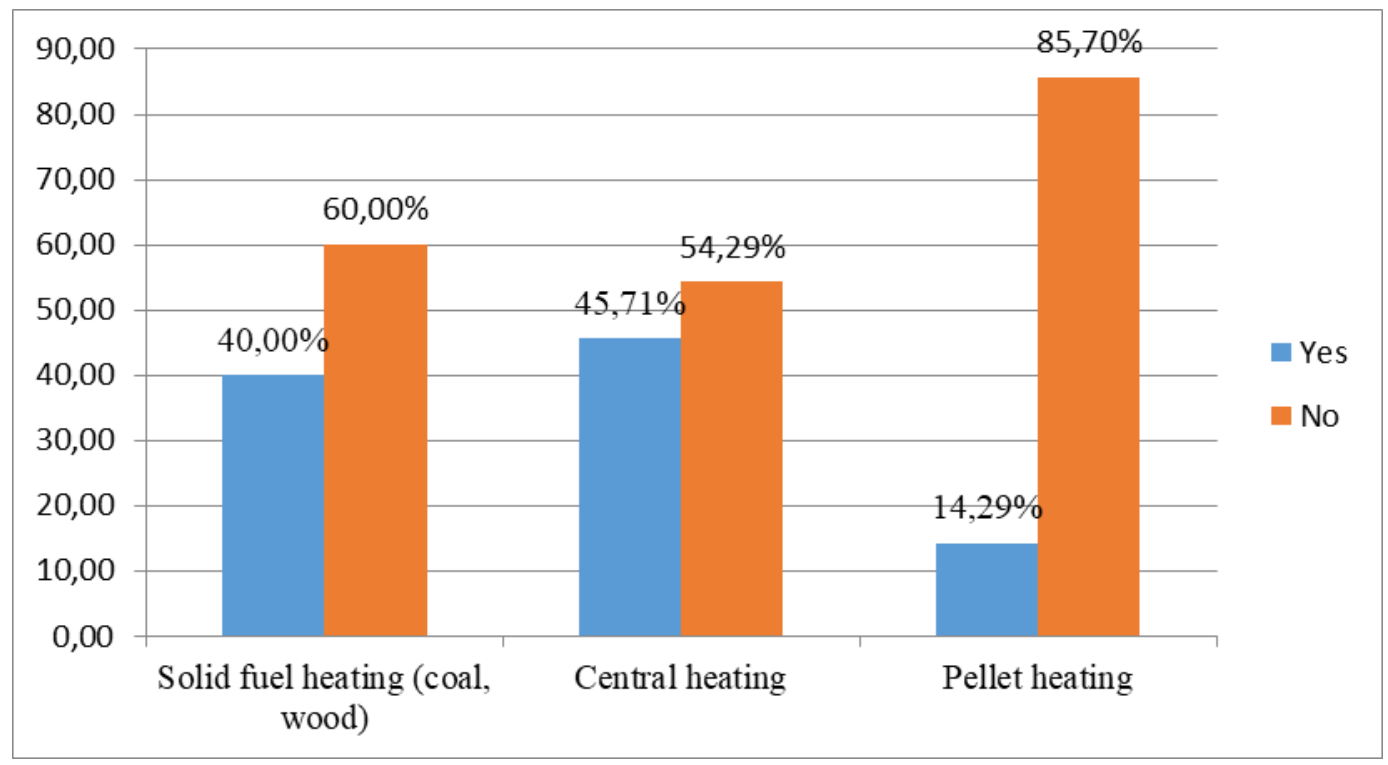

Graph 3. Which type of fuel do you use in your own household?

Source: Authors' creation

The aim of this education was that students realize that cost-effectiveness - in the aspect of energy consumption and energy efficiency - is on the side of using pellet as a main source of heating in households. The result, presented in Graph 4, was obvious, considering that 68 or $97.14 \%$ students agreed with our given statement. 


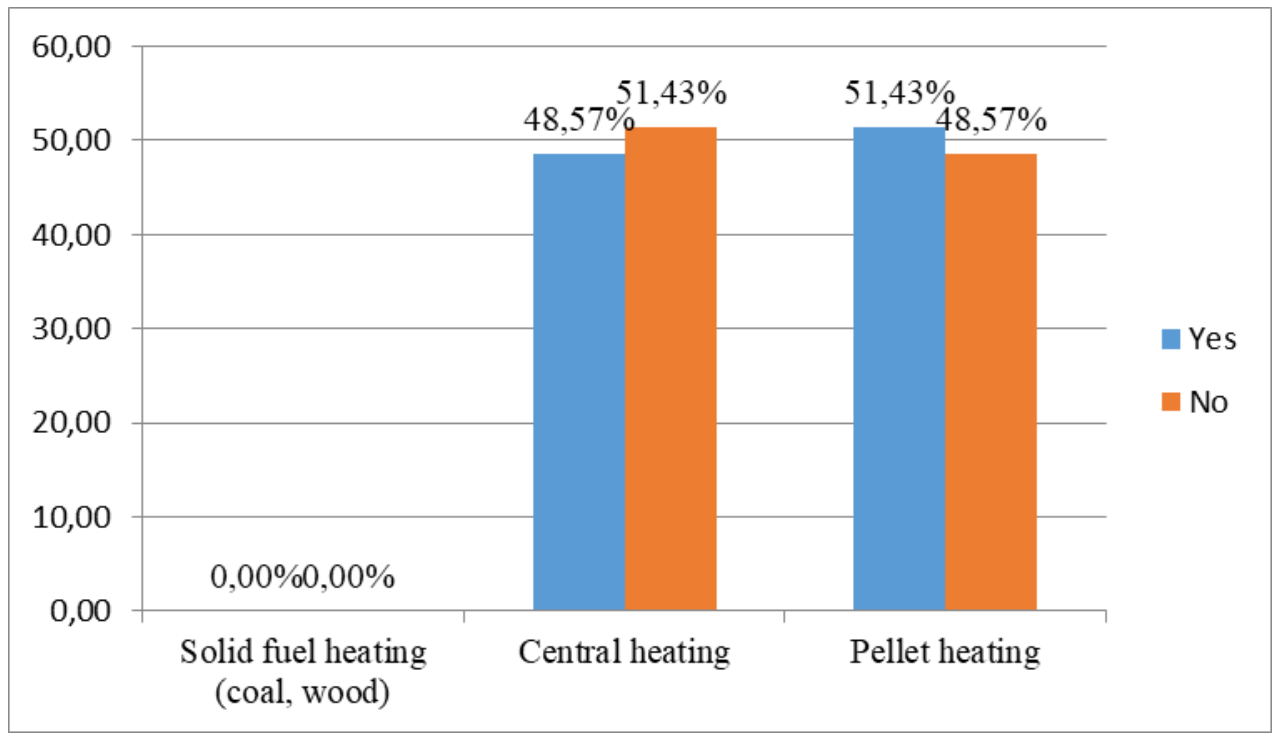

Source: Author's creation

\section{Graph 4. In your opinion, which type of fuel is energy efficient and cost-effective?}

All previously presented research results, in their logical flow, point to the conclusion based on attitudes of all 70 respondents (100\%), which is that continuing educations in the field of energy efficiency and renewable energy sources are necessary, especially at the Faculty of Economics and Business at University in Tuzla. Those would be greatly supported, according to students, through a media campaign and promotion of the importance of using renewable energy sources.

\section{Conclusions and Recommendations}

The Federation of Bosnia and Herzegovina Development Strategy, for the period 2010-2020, has allocated the following within the Framework Objectives and Strategically Priority Development Goals of the Federation of B\&H: (1) Sustainable growth and development, ecology and development of energy potentials,

(2) Utilization of renewable and non-renewable natural resources in securing sustainable development, and thereby defining concrete measures that will contribute to increasing the level of environmental protection and energy efficiency, that is, the use of renewable energy sources. In this context, youth have been given a special role in promoting energy efficiency and the use of renewable energy sources in order to raise public awareness and strengthen the role of young people in the field.

One of the fundamental aims derived from the research findings in this paper, mentioned in the theoretical concept of the research, is focused, among other things, on changing behavior and awareness of youth asan individual, for example, in terms of rationalizing their energy consumption in daily life and attitudes towards renewable energy sources. We may say freely that this goal is related to the "idea of responsibility", the particular responsibility of an individual, that is, a young person.

Furthermore, a potential idea or conclusion that emerges from this research could be cited - introduction of various content in the field of energy efficiency and renewable energy sources into teaching syllabi as a special form of education and training, thus facilitating the realization of clear educational goals about energy.

In view of the foregoing, we highlight the following conclusions of the research conducted. Certainly, we believe that each of them can be a good starting or fundamental basis for some further (future) research.

- Low level of awareness among youth regarding knowledge about energy efficiency and renewable energy sources;

- Lack of public participation of youth in the decision-making process, in terms of energy economy, in general;

- The education system in B\&H does not pay sufficient attention to environmental protection, rational use of energy and renewable energy sources;

- Awareness and knowledge about energy efficiency among youth and citizens in general should be constantly extended;

- Youth and children should be educated in primary and secondary schools and colleges in order to understand that this is an area that contributes to the general development of society;

- It is necessary to continuously encourage scientific and research work of young people in the field of energy efficiency and use of renewable energy sources;

- Increasing environmental awareness of citizens in every local community should be done, especially with youth; 
- Competent government institutions should support public awareness-raising activities on energy waste and the benefits of energy efficiency and renewable energy and environmental protection, as well as education programs in this field.

\section{References}

Kavedžija, I. (2009). Energijaiodgovornost - model obrazovanjazademokratskograđanstvoiobnovljiviizvorienergije. Soc. ekol. Vol. 18, No. 1, Zagreb. On line:

https://bib.irb.hr/datoteka/460332.01_kavedzija042_kavedzija005_jankovicBook_SE_1_09.pdf(available at: January 2020)

Citizen Partipation Energy Eficiency Action Planning (2016). On line:www.energy-community.org > dam > B\&H_NEEAP_2016_2018_042017 (Available at: February 2020)

Pregledzakonskihobaveza JLS u RepubliciSrpskoj Sarajevo, 2016, Deutsche Gesellschaft-a für Internationale Zusammenarbeit (GIZ). On line: http://www.alvrs.com/v1/media/djcatalog/4.\%20Zakonske\%20obaveze\%20EE_JLS_RS.pdf(Available at: February 2020)

Akcioni plan energetskeefikasnostiCrne Gore za period 2019-2021,Crna Gora ministarstvoekonomije, 2019. on line:www.energy-community.org > dam > 4thNEEAP_MO_201907 (Available at: February 2020)

Topić, D. et.al. (2018). Obnovljivi izvorienergije i energetska učinkovitostza ruralna područja, Interreg V-A Programa suradnje Mađarska-Hrvatska 2014.-2020, MTA KRTK Institute for Regional Studies. On line: https://bib.irb.hr/datoteka/984785.rures_cro_final_2018_12_24.pdf(Available at: February 2020)

Okvirna energetska strategija Federacije Bosne i Hercegovine do 2035. On line:

http://www.mvteo.gov.ba/data/Home/Dokumenti/Energetika/Okvirna_energetska_strategija_Bosne_i_Hercegovine_do _2035._HR_FINALNA.PDF, (Available at: February 2020)

Kolega, V., Bošnjak, D. (2015). EnergetskaefikasnostuasocijacijamalokalnihsamoupravaEeMAStalnakonferencijagradovaiopština- SavezgradovaiopštinaSrbije, Beograd. On line: https://balkangreenenergynews.com/rs/mapa-puta-odrzivog-koristenja-energije-za-asocijacije-lokalnesamouprave-u-zemljama-jugoistocne-evrope/(Available at: February 2020)

Građani za Evropu.Energijaiokoliš - Preporukecivilnogdruštvazabrži put prema EU 2011. on line: https://energis.ba/publikacija-energija-i-okolis-u-B\&H-preporuke-civilnog-drustva-za-brzi-put-premaeu/(Available at: February 2020) 